\title{
Research Paper Status of agriculture labour scarcity in North Eastern Karnataka
}

Gunabhagya and Amrutha T. Joshi

See end of the paper for authors' affiliations

Correspondence to :

\section{Gunabhagya}

Department of Agricultural Economics, College of Agriculture (U.A.S.), Raichur (Karnataka) India

Email : guna811@ gmail.com

Paper History :

Received : 15.01.2019;

Revised : 06.02.2019;

Accepted : 16.02 .2019
ABSTRACT : Today agriculture labour has become the most important component in Indian agriculture. A little less than half of the total cost of production of field crops is for labour. It is much more for labour intensive crops such as sugarcane, cotton, vegetables etc. Despite a fall in its share in GDP, the prominence of agriculture has not decreased. One of the reasons that can be related to this is that the dependence of the rural work- force on agriculture for employment has not declined in proportion to the sectoral contribution to the GDP. The proportion of agricultural workers to the total workers has been declining over the years, while the corresponding ratio in the secondary and tertiary sectors is on the rise. Pursuant to this, following impacts have been predominantly noticed in agriculture in recent years: reduction in crop yield, reduction in cropping intensity and changes in traditional cropping pattern. Scarcity of farm labourers is a grave concern for the farmers, who may not even hesitate to abandon farming. The acute shortage of agricultural labourers in the state has led the delay in crop establishment, poor crop growth, no or untimely weeding, irrational use of fertilizers, insufficient irrigation to crops etc. which has pressed Indian farmers to shift from farming to non-farm activities. It was revealed from the study that, the labour shortage was to the extent of fifty per cent. Markov chain analysis on the changes in cropping pattern in Raichur district indicated that, pulses had been the most stable crops among the major crop groups grown in the district. In Koppal district, plantation crops had retained 70 per cent of their previous years' share of area. In Kalaburagi district, the highest probability retention was observed in area of pulses i.e., around 86 per cent of their previous years' area which was evident that, farmers are shifting towards the low labour intensive crops it may affects the future food security.

KEY WORDS : Agriculture labour scarcity, GDP

How To Cite This PAper : Gunabhagya and Joshi, Amrutha T. (2019). Status of agriculture labour scarcity in North Eastern Karnataka. Internat. Res. J. Agric. Eco. \& Stat., 10 (1) : 108-114, DOI : 10.15740/HAS/IRJAES/ 10.1/108-114. Copyright@ 2019: Hind Agri-Horticultural Society. 